\title{
Classroom Sources of English Language Anxiety: A Study of Fresh Engineering Students at Mehran UET, Pakistan
}

\author{
Illahi Bux ${ }^{1}$, Rafique A. Memon ${ }^{1}$, Shabana Sartaj ${ }^{2}$, Jahangir Bhatti ${ }^{3}$, Abdul Sattar Gopang ${ }^{4} \&$ Noor Muhammad \\ Angaria $^{5}$ \\ ${ }^{1}$ Institute of English Language \& Literature, University of Sindh, Jamshoro, Pakistan \\ ${ }^{2}$ Sindh Agriculture University, Tando Jam, Pakistan \\ ${ }^{3}$ Ontario Institute for Studies in Education, University of Toronto, Canada \\ ${ }^{4}$ Faculty of Education, University of Sindh, Jamshoro, Pakistan \\ ${ }^{5}$ Faculty of Education, LUAWMS, Baluchistan, Pakistan \\ Correspondence: Illahi Bux, Institute of English Language \& Literature, University of Sindh, Jamshoro, Pakistan. \\ E-mail: illahi_gopang1234@yahoo.com
}

Received: January 20, 2018 Accepted: December 21, 2018 Online Published: January 29, 2019

doi:10.5539/ijel.v9n2p30 URL: https://doi.org/10.5539/ijel.v9n2p30

\begin{abstract}
The current study investigated anxiety-provoking classroom sources among undergraduate engineering students at Mehran UET, Pakistan. In this study, the participants (female 105 male 116) participated. The data were collected via questionnaire FLCAS and semi-structured interviews. The objective of this study was to identify classroom sources of anxiety quantitatively and qualitatively. The findings of study suggested some main sources of anxiety among fresh engineering students: (1) test anxiety; (2) apprehension in communication; (3) fear of negative evaluation; (4) presentation in English; (5) English language instructor; (6) competitiveness in English language; (7) negative self-evaluation; (8) individual tasks in classroom; (9) fear of making errors in English classroom; (10) English language difficulties. The participants have self-reported the main sources of anxiety in English language learning. These sources also confirm previous research on anxiety-causing sources among foreign language learners.
\end{abstract}

Keywords: foreign language anxiety, sources of anxiety, classroom sources of English language anxiety

\section{Introduction}

For the last three decades, anxiety has been the main affective variables in students' learning a foreign language (Horwitz, 2016). A few studies in anxiety have also indicated correlation either positive or negative between its causes and effects in language learning (Horwitz, 1986; MacIntyre \& Gardner, 1994; Aida, 1994; Mari et al., 2012; MacIntyre \& Gregersen, 2012; Trang, 2012). Horwitz, Horwitz and Cope (1986) have described anxiety as the subjective feeling of tension, apprehension, nervousness and worry associated with an arousal of the autonomic nervous system (p. 118). Feelings of tension and nervousness in language learning negatively contribute to students' process of foreign language learning (Gopang, 2016; 2017; Ohata, 2005). Moreover, Horwitz et al. (1986) and Woodrow (2006) argue that learners may be considered good at skills; however, when speaking skill of foreign language is tested, learners have mental block against it. And this basically creates hindrance to their learning. So, students' feelings of nervousness, stress, and anxiety play a role of mental block and affect communication (Horwitz et al., 1986). Anxiety as one of the emotions has negatively affected language learning. What motivated this research was the sources that caused anxiety among engineering undergraduates at Mehran UET. As MacIntyre and Gregorson (2013) have rightly mentioned that such classroom research in anxiety could create appropriate awareness in regarding to teaching and learning practices. This study is an attempt to provide an accurate and deep understanding about engineering students' sources of anxiety with interesting findings.

\section{Literature Review}

Research on factors or sources which causes anxiety is carried out in different contexts. In the study of Young (1991), six factors were reported: (1) personal and interpersonal issues; (2) instructor and learner interactions; (3) 
classroom procedures; (4) language testing; (5) instructor beliefs about language learning; (6) learner beliefs about language learning. Classroom procedures were broken into (1) spontaneous role play in front of the class; (2) speaking in front of the class; (3) oral presentations or skits in front of the class; (4) presenting a prepared dialogue in front of the class; and (5) writing work on the board. Error correction also turned out to play an important role (Young, 1990; 1991). Bailey, Daley and Onwuegbuzie (1999) also proposed that students are likely to experience anxiety in the case of ambiguity, novelty, conspicuousness, and prior to their experiences and evaluation. On account of these reasons, anxiety is linked with language classroom. It is also debated that learners may also have few concerns about anxiety in different classes. In foreign language classroom, learners are particularly concerned with his/her negative evaluation. So they show much concern regarding their negative self-evaluation in the class. The most general situation is where anxiety students negatively analyze their own self concepts concerning many facets of learning language. In other words, they exhibit low self-respect (Lui \& Jackson, 2008; Gkonou, 2011). In the light of factors, the study of Onwuegbuzie et al. (1999) suggested that learners age, achievement, competence, and ideal-self engender FLA among learners. Additionally, the diversity in academic life; background, interests, general and specific, aspiration, integrative and instrumental orientations have also a large share in foreign language anxiety. More importantly, the findings of this study indicate that $40 \%$ of total variance, reported seven predictors being significant in foreign language anxiety. In the same vein, Wen and Clement (2003) and Peng (2007) conducted research to identify sources of anxiety among Chinese students at university level. Their studies indicated eight factors such as communicative competence, language anxiety, risk taking, learners' beliefs, classroom environment, group cohesiveness, teacher support, and classroom organization. Some studies indicate sources of anxiety such as, limited ability in the target language (Horwitz, Tallon, \& Luo, 2010); learning beliefs and expectations (Horwitz et al., 1986; Price, 1991; Young, 1994; Harati, 2014; Gopang et al., 2017); classroom activities, role plays, oral presentations, skits, and written work (Young, 1994); teachers, unsupportive, unsympathetic, judgmental, and inattentive (Aida,1994); unfamiliar method of error correction in classroom (Young, 1991); students' background and personality factors - self-worth, academic competence and achievement in TL (Onwuegbuzie et al., 1999; 2000; Gregerson \& Horwitz, 2002); introversion v/s extraversion (Ohata, 2005); lack of motivation (Gopang, 2016). These sources of anxiety generate feelings of tensions and nervousness among learners. Numerous studies mentioned above have highlighted various sources of provoking foreign language anxiety among learners. Pedagogical, social, psychological, behavioural demographic and personality traits are common factors causing nervousness among students at university level.

Tallon (2008) reviewed foreign language anxiety literature and identified different sources of anxiety among learners. In this study, these sources are categorized as (1) learner characteristics, (2) teacher characteristics and (3) classroom procedures. Language anxiety is triggered because learner, teacher and classroom. Learners characteristic include "low self-esteem low, competitiveness, self-perceived low level of ability, communication apprehension, lack of group membership with peers, and beliefs about language learning" (p. 3). Shabani (2012) researched levels and sources of FLA and FNE of Irani students. The results showed that students suffered from anxiety and fear of negative evaluation in classroom. The fear of failing class and fear of unfavourable impression on others were reported respectively, negative judgment by others, and fear of doing and saying wrong things. Anxiety-provoking sources in research of Merç (2011) classified into six main categories such as: students and class profiles, classroom management, teaching procedures, being observed, mentors, miscellaneous. Most anxiety producing situations for student teacher teaching take place through the medium of English. For example, unexpected questions, teaching speaking skills, student' lack of interest in English class, teachers do not control students, teaching English to students from English speaking country, observing English classes, teaching listening and teaching English culture. Moreover, anxiety sources associated teaching such as: English proficiency, lack of confidence, lack of knowledge about the subject, insufficient class preparation, and non-native compared to native speakers, fear of negative evaluation, and lack of teaching experience (Kim \& Kim, 2004, as cited in Merç, 2011). The current study is also in line with previous research that described anxiety inducing sources at tertiary level in the world.

\section{Methodology}

In this research, a mixed methods approach was employed to identify sources which provoked anxiety among fresh engineering students at Mehran University of Engineering and Technology, Pakistan. This research study could suggest more insightful and informative findings on anxiety of students who are enrolled to learn English language course.

\subsection{Research Objective}

The present study was designed to find out anxiety-provoking sources among fresh undergraduate engineering students at university level in Pakistan. 


\subsection{Research Question}

What are the classroom sources which cause engineering students' anxiety in learning English language course at the university level in Pakistan?

\subsection{Concurrent Triangulation Design}

The triangulation was found to be necessary part of this research and researchers followed the idea of Greene (2007) who argued that methodological triangulation tends to convert, corroborate and correspond findings from a multiple research method. The researchers sought this approach keeping some limitations of survey methods such as questionnaires. Moreover, to explore anxiety-inducing sources, the semi-structured interviews were also conducted to extend the validity, trustworthiness and quality of interpretation and inference. Greene (2007) has written that triangulation does not only "seek broader, deeper and more comprehensive social understanding by using methods that tape into different facets or dimensions of the same complex phenomenon", but it also produces "results from the different methods which serve to elaborate, enhance, deepen, and broaden the overall interpretations and inferences from the study" (p. 101). The rationale of making triangulation as the part of this study is what the researcher might fail to investigate through questionnaires, he might achieve via semi-structured face to face interviews. Mixed methods were employed for confirmation cross-validation, or corroboration of results in a single study (Creswell, 2003). Using both methods concurrently is to overcome a weakness in the use of single method with strengths of another. The purpose of using the quantitative and qualitative methods is similar, and the methods are triangulated in order to have an extensive understanding of students' anxiety provoking sources language anxiety and language beliefs.

\subsection{Foreign Language Classroom Anxiety Scale}

Horwitz et al. (1986) developed the scale known as FLCAS for anxiety investigation and measurement. The scale has been reported with high inter-rater reliability (Aida, 1994). FLCAS consists of 33 items with possible range to 165 ; if the number is higher and as a result it indicates anxiety in high degree. The internal consistency in scale is reported .93 , by using the sample of 108 participants in the study, while test-retest reliability was found .83 , and this period extended till 8 weeks (Horwitz et al., 1986). In the terms of construct validity, Foreign Language Classroom Anxiety is validated in the use of correlations showing distinctiveness of the scale from other types of anxiety measurements (Horwitz, 2010). The FLCAS is self-report instrument, is a standard instrument for anxiety measurement. This scale measures the level of foreign language anxiety acknowledged by negative performance, social comparisons, psychological symptoms and avoidance behaviors. The sources of developing FLCAS were student self-reports, clinical experience, and a review of related instruments. The review of related literature on anxiety was the main way for development of FLCAS.

\subsection{Validity and Reliability}

In the context of reliability, Aida (1994) conducted a study replicating FLCAS on sample of 96 students who were enrolled in the Japanese course. This study reported .94 a Cronbach's alpha coefficient, and it also confirms previous reliability score of the scale. Now, reliability of the instrument is also supported by some other studies so far (see Horwitz, 1991, for validity). It implies that the instrument is reliable and valid for further studies on the foreign language classroom anxiety (See Horwitz, 2016, for validity). Thus, some studies have reported high reliability in research. The studies of Wu (2010) and Cheng (2005) have reported high Cronbach alpha .94, .95. These studies were conducted on Taiwanese students. However, Cheng, (2005) used the same model and results of Cronbach alpha coefficient was .96. It was checked with the pilot study of 20 respondents. The model has predictive validity demonstrated in the study. This is proved through correlation of foreign language anxiety and course grades and achievement tests $(\mathrm{r}=.52, \mathrm{p}=.001, \mathrm{n}=108)$. Likewise, Waseem and Jibeen (2013) reported Cronbach's alpha .92. Significantly, these studies indicate that FLCAS is reliable for FLA research. Keeping in view of reliability, the current study checked the inter-reliability of FLCAS using SPSS software. It was checked with 70 participants during study. The Cronbach alpha was reported .85 .

\subsection{Semi-Structured Interviews}

To add some more insightful view of anxiety-provoking sources, the semi-structure interviews were conducted. Before the interviews, the researchers being unbiased approached students for their consent as an interviewee. The participants were asked if they would like to have time for decision. The researcher audio recorded, transcribed and translated all of the interviews in the time of analysis. In addition, the participant's responses were coded with the purpose to help identifying of patterns, relationships and themes that came out of qualitative data. All the participants were Pakistani nationals. 


\subsection{Participants}

Data were collected from the participants $(\mathrm{n}=221)$ included female 105 and male 116 . The participants were enrolled to who learn English language. The students completed questionnaire FLCAS. In order to have in depth understanding of anxiety-provoking sources, some students $(n=10)$ were interviewed who were enrolled to English language course. For face to face semi-structured interviews, the researcher selected participants randomly. For the implementation of this process, 10 interviewees are asked for their subjective responses on anxiety. The participants were involved from various departments/disciplines/faculties. A detailed selection procedure is provided.

Table 1. Descriptive statistics

\begin{tabular}{ll}
\hline Department & No. of participants \\
\hline Software Engineering & 30 \\
Civil Engineering & 30 \\
Bio-medical engineering & 40 \\
Computer Systems Engineering & 25 \\
Telecommunication Engineering & 20 \\
Electrical Engineering & 17 \\
Electronics Engineering & 20 \\
Petroleum and Gas & 20 \\
Mechanical & 19 \\
& 221 \\
\hline
\end{tabular}

\subsection{Site of the Research}

For this study, Mehran University of Engineering and Technology was selected. There are many reasons for the selection of research site. Firstly, the researchers were from Jamshoro, Sindh province. They had an academic social networking that could assist them in data collection process. Secondly, to the best of researchers' knowledge, no study on engineering students' anxiety-provoking sources about language learning was conducted so far. Thirdly, teaching of English language course ranged for specific period of time. This short period of span motivated researchers to choose engineering students. Later, Director of ELDC was requested to grant permission for data collection. After these approvals, the investigators started the process and got access to the participants at the university.

FLCAS questionnaire data were analyzed by using SPSS 21 . The descriptive statistics in terms of mean and standard deviations were presented to identify main sources of anxiety. However, to analyze semi-structure interviews, a qualitative content analysis was employed to generate themes. This method can be referred to as "a research method for subjective interpretation of the content of text data through the systematic classification process of coding and identifying themes or patterns" (Hsieh \& Shannon, 2005, p. 1278). It is "a method for systematically describing the meaning of qualitative material" (Schreier, 2012, p. 1). In the view of these useful understandings, the content analysis was used to analyze the interviews of the participants.

\section{Data Analysis}

Research Question: What are the classroom sources which cause engineering students' anxiety in learning English language course at the university level in Pakistan?

The research question investigates language anxiety inducing-sources in student's English language learning at the university.

Table 2. Descriptive statistics

\begin{tabular}{llllll}
\hline & $\mathrm{N}$ & Minimum & Maximum & Mean & Std. Deviation \\
\hline Communication apprehension & 221 & 25.00 & 60.00 & 36.3529 & 5.24771 \\
Test anxiety & 221 & 32.00 & 65.00 & 47.9819 & 6.60369 \\
Fear of negative evaluation & 221 & 12.00 & 32.00 & 23.0950 & 3.86653 \\
Valid N (listwise) & 221 & & & & \\
\hline
\end{tabular}


The above table shows sources of foreign language anxiety among engineering students at the university. Main sources of anxiety are communication apprehension, fear of negative evaluation and test anxiety in English language classroom.

More importantly, apprehension in speaking foreign language is identified as the important source of anxiety. The subjects mark the apprehension in communication as the provoking source of anxiety. Communication apprehension is what students feel while speaking English in a class. Moreover, fear of negative evaluation is rated as one of the main sources of foreign language anxiety. The descriptive results indicate that a great number of participants feel fear in evaluation. As shown that FLCAS is the reflective of CA, TA and FNE about foreign language learning. However, according to Horwitz (2010), the theory of FLA is not limited to these components rather it has wider perspective of anxiety specific to language learning. In regard to anxiety sources, 33 items of FLCAS describe students fear from their teacher, error correction, classmates, other people, and attitude towards English, speaking in front of others, low self-esteem, presentation, comparison with fellows, competitive nature, and consequences of failure in English class.

Engineering students experience anxiety due to the quantitative sources which are identified as communication, test and evaluation in English class. Sources generated from the semi-structured interviews are presented as main and sub sources of foreign language anxiety.

\subsection{Foreign Language Anxiety}

\subsubsection{Communication Apprehension}

The participants reported that they are afraid of speaking English in a classroom. Their responses were recorded such as "I do not speak English because I cannot control my mistakes", a female participant. "Sir, when I try to speak English I forget what I am going to speak", a male participant. "It is terrible to speak when you think you are speaking either wrong or right", a male participant. "I am not sure what I speak if the teacher calls me so I try to avoid speaking", a female participant. These responses from both male and female participants describe their communication apprehension as the source of FLA.

\subsubsection{Test Anxiety}

As shown in Table 2, test anxiety is the first main source of anxiety in engineering students at Mehran UET. Simultaneously, the interview data also support quantitative results indicating test anxiety as one of the sources for learners who are enrolled to learn English language. One of the male students expressed that "I always avoid going to classes when the test is scheduled". Another male student showed his feelings in these words "Oh no test, it is painful because of my painful English". Certain expressions about the test are: "I am good at other subjects but I dislike test in English classes, in English class, one day I gave a test and it went bad so I decided not to appear again." Now it may be noticed from these subjective views that students do not prefer tests in English classes.

\subsubsection{Fear of Negative Evaluation}

In classroom, the teacher evaluates the performance of the students. In addition to this, students also think they are evaluated by their fellows at the same time. In this regard, students express fear of negatively marked or evaluated in front of other people. Here are some responses recorded from male and female participants. "To be honest, I do not like when the teacher corrects my mistakes in front of my fellows", a student. "When my classmates start gazing at me during class, I do not know what I should do so I stop; it is really disturbing", another student said. "Teacher's evaluation is challenging for me. This is the biggest issue for me", a student expressed it. According to the theory of FLA, the basic sources of anxiety are presented in the study. Moreover, during the semi-structured interviews, the study has also identified anxiety-inducing sources. The sources are derived from individual interviews which were conducted to answer research question.

\subsection{Presentation in English}

This source of anxiety has been replicated. In earlier studies, presentation was discussed as the source of anxiety among foreign language learners (Tanveer, 2007; Gopang, 2016; Jones, 2004). Many students expressed their feelings of anxiety during the presentation in a class. One of the students reported that:

I feel nervous when I am invited for presentation in a classroom without preparation. This is very painful for me and it always happens with me. I run out of my senses when I hear that I have to speak in English in front of my teacher. When I am invited to present something I soon forget what I am going to say in front of all. I am very... ....um.... very afraid of speaking English. 
Another student mentioned somewhat the same difficulty:

Well, I am without words to speak. I then say oh my god I am going to die today because I have no confidence to say. It is very pathetic situation in which neither you can refuse the teacher nor you have material to speak. Moreover, Sir, honestly, I do not give presentations because my English is broken.

Similarly, another participant discussed that:

I forget all when a teacher takes my name in front of fellows for comments or participation in the classroom. Sir, my class fellows start judging me when I speak English. This idea beats me and I fail to say what I am supposed to.

One of the participants also stated nervousness in presentation:

When I have to give presentation in the English class which I haven't prepared in advance, I am then gone. You know, when you are not prepared for a topic and not sure what to say and you are called for speaking something suddenly. This is terrible. It causes anxiety in me.

These interview excerpts of the participants reveal that the presentation was the main source of anxiety in classroom. Their nervousness, shyness and discomfort are created when they are called for presentation in English class.

\subsection{English Language Instructor}

The participants of this study expressed the English language teacher as the source of their anxiety in a classroom. They also added teacher's attitude, age, and English proficiency as the sources of anxiety in their classroom learning.

\subsubsection{Inexperienced Instructor}

One student expressed: Sir you see that if we learn under non-qualified teacher in English who has no experience in teaching language, then there is no learning of foreign language. I should not say but this is the fact I am really afraid of senior teachers who are teaching English language. I do not comfortable. The age of the teacher is a matter of great concern. I want to learn English language under guidance of young instructors at the university.

\subsubsection{Teachers' Attitude}

Another student stated:

My language anxiety depends on teacher if he is cool I am ok if not I am disturbed and confused. By saying this I mean all about the teacher; if it happens, I do not understand what the teacher is teaching and suddenly she/he asks questions from that topic I am then beaten. I get confused what to do right now.

Similar to the above thought, another student pointed out that:

I am relaxed in other classes because I am prepared for them. I am very uncomfortable in English class because the teacher only speaks in English which I do not understand. I get bored very soon. One thing more, my English teacher often speaks so fast that I do not understand. I am weak I do not learn anything during the lecture so my that day is wasted.

In addition, one of the students told that:

I feel confused when the English teacher has no prepared lesson plan what he/she is saying. I think he she may be having lack of proficiency or aptitude in foreign language. I am afraid of when I see the teacher is beating about the bush. I keep on thinking this and that.

These subjective responses indicate that the teacher is the source of creating anxiety among engineering students at the university level. This anxiety-provoking source confirms previous research that highlighted the same finding.

\subsection{Competitiveness in English Language}

During the interviews, many participants viewed their classmates as the source of anxiety in learning English. They told that they always think others to be proficient in English. Particularly, the subjects showed a great concern over other people in classroom.

One of the participants said: I always wish to speak English fluently but when I hear others speaking good English I do not wish to. I think they are best. Likewise, another student endorsed saying that

Well sir, I compare myself with others and I know that I am better in speaking. English is my dream so I am learning it with core of heart to beat others in classroom. 


\subsubsection{Comparison}

One student also put the same idea in this way:

I feel very jealous of if I see others are going high in learning English. It makes me anxious as well as competent. I think this anxiety is good for me. You know what it is that in learning it is only competition that sometimes leave you in panic.

In the same vein, another student reported:

When I am the first to speak, I am ok. If I am going to speak after others speak, I am worried. I also think that if you do not compare yourself with others in learning language, then I think you cannot learn fast.

\subsubsection{Avoidance of Others' Remarks}

Another mentioned that:

I always dislike my fellow's comments such as why you are always in front of the teacher. You want more marks or grads. This sometimes makes me boring. They are jealous of my success perhaps I think they should be because I am perfect.

It is reported that many students get jealous of their fellows' foreign language proficiency level. The competiveness among the engineering students is very much indicative that they compete in language learning class.

\subsection{Negative Self-Evaluation}

Many students expressed that they think themselves inferior to others in speaking English language. They told that their English was not so good so that they think others have high proficiency level in English compared to them. During interviews, students reported that their English was poor because of their early experience of learning at the school or college. One of the participants discussed that

Sir, I am from rural area of Sindh, when I hear others speaking English I feel not to speak. I think I am left behind in English because sir, you see others are from Beacon schools and county colleges.

The participants also mentioned that they had no confidence. As one of the participants said, "sir, I always feel that I am not able to compete others in English class so I blame myself". These alarming expressions suggest that students negatively assess themselves in a classroom. Many students keep on thinking that they have low self-esteem because they look down upon themselves. As expressed in these words "I feel I am very weak in English so I cannot speak English. I love English but I keep on thinking this and that." "I don't know why others understand and I do not and I think I am not going to be as good as they are in English language classes." As expressed by the participants in the interviews, the results suggest that they self-negatively evaluate themselves and they think others to be better and best. This sense created low self-esteem among engineering students. With thoughts of others high proficiency level, they lower their self in language learning classes.

\subsection{Individual Tasks in Classroom}

Assignments and tasks in classroom are common practices in teaching foreign languages. When the researcher interviewed participants about the sources of anxiety in classroom, they reported individual task or assignment in English as one of the sources of anxiety. As mentioned by one of the students:

I feel very anxious when the teacher asks me to do any activity individually. Sometimes, sir, I even do not understand what to do so I get confused.

Another expressed his/her view:

I feel good when I work with others in English classes. I actively participate in classroom activities but I fear I cannot do it lonely.

Similarly, another narrated:

I get bored with overloaded assignments which even I fail to understand so I would I do these. You have to do this and that I am only busy in hearing these words in English class. Heavy and overloaded work creates discomfort in me. And when I fail to handle it beats me. You are only busy doing tasks in which I feel uncomfortable.

One of the students said:

Assignments make me anxious which sometimes I do not understand and I am unable to ask my fellows because you feel shy and get underestimated. 
These expressive views about individual tasks or assignments make students nervous in a classroom. There may be some reasons behind this. Assignments might be difficult or complex. Students could not understand these tasks in a class. May be, the teacher could not make them understand he/she only asked submission of assignments or tasks.

Ok I agree activity is fine. It is learning process but when it is properly explained in class. Sir, see the teacher should make sure that everyone understands what they are going to do.

This expression indicates that students' learning may be guaranteed. Similar to this, another student burst into emotions and said:

When I am doing anything in groups, I am confident; but I cannot do it alone because I lose confidence.

These insightful views of the participants describe their anxiety-bound tasks and assignments.

\subsection{Fear of Making Errors in English Classroom}

The previous research has described students' errors as one of the learning blocks in foreign language. In classroom, students commit errors and they do not like these errors because of their self-esteem (Gopang, 2016; Tanveer \& Wang, 2005). The subjects told that they feared of making mistakes in classroom. The findings of this study support the past research that discovered it as one of the sources of anxiety in learners. In individual interviews, many participants focused this fear frequently.

As expressed by one of the students:

When I speak I make many mistakes in English because it is difficult language. My mistakes lay bad impression in a classroom so I avoid taking part in speaking activities.

Another student narrated that:

I am afraid of unwanted mistakes which I dislike but unconsciously I make during English classes. This seems to me as terrible. I hate it honestly.

Similar to these expressions, a student stated:

Well, no mistakes in English. That is my motto in learning language. People say make mistakes and you learn but I do not favour this because it is the cause of anxiety.

These subjective results reveal that students are afraid of making errors in English classes. The students' attitude towards making errors is avoidable because they are perhaps afraid of being negatively evaluated.

\subsection{English Language Difficulties}

Many students showed a great concern about their difficulties in English accent, pronunciation, vocabulary, and grammar. One of the anxiety-provoking sources is English language difficulties encountered by the students. As one of the students mentioned, "I wish to speak like the British but I cannot achieve their accent so it seems I am speaking English in Sindh." Similar to this, another narrated, "I want to speak correct and accurate English. I do not like my accent of speaking English that is one the reasons I do not speak in front of the teacher and others." These words indicate students' difficulty in English language. As expressed by another student, "I love the American accent the way Americans speak English but my accent is not good. I want to improve but I think I am failing. I am dissatisfied with my accent. My bad accent makes me uncomfortable." Regarding pronunciation, "I am worried about my pronunciations in English class. I sometimes mispronounce because I don't know them. So I avoid speaking English." Another participant stated "well, grammar is good but grammar rules and structure disturb me. I feel confused with its structure of sentences in English." In the same light of thought, some other expressions of the students such as, "Rules and regulations of grammar beat me and I get nervous. My English is good but grammar is weak therefore I don't think it should be focused in classroom. When I speak English I do not know which tense I am using." "Sir, I don't know where the articles, (A, An, \& The) are supposed to be used in a sentence. When I write my teacher detects these article errors." "I do not have good vocabulary in English so I feel my skills are affected because of lack of words." "You know what happens, usually I don't have words for expressions, ideas and feelings." "My grammar and vocabulary are very poor I commit many errors in writing." The previous research has confirmed that foreign language learners face linguistic difficulties in learning. The present study is not different from the past research in this regard (Tanveer, 2007).

\section{Discussion}

The total descriptive mean score of communication apprehension is $(\mathrm{M}=36.35, \mathrm{SD}=5.24)$. In addition to this, mean scores of test anxiety goes higher $(\mathrm{M}=47.98, \mathrm{SD}=6.60)$. The last category of FLCAS is fear of negative evaluation and its descriptive score is $(\mathrm{M}=23.09, \mathrm{SD}=3.86)$ (See Table 2). The quantitative part of the first 
research question indicates anxiety in test, apprehension in communication and negative evaluation in a classroom as one of the basic sources of foreign language anxiety in engineering students at Mehran UET. The FLCAS is reflective of CA, TA and FNE. The subjects of this study reported that they were anxious about giving tests, communicating in English and fear of being negatively evaluated by others. The qualitative part of this question has identified some other classroom sources of FLA in learning. The sources of anxiety are (1) presentation in English; (2) English language instructor; (3) competitiveness in English language; (4) negative self-evaluation; (5) individual tasks in classroom; (6) fear of making errors in English classroom; (7) English Language difficulties. The substantial number of the participants told that their anxiety is mainly caused by highlighted sources in learning. The findings support the earlier research on anxiety-provoking sources. In sum up, the quantitative and qualitative responses were taken to properly address the research question. This triangulation research design now confirmed that some main anxiety-provoking sources through quantitative and qualitative nature of the research.

The results of this study showed test anxiety with high mean score which contrasted with a few studies indicated high mean scores in communication apprehension (Koch \& Terrel, 1991; Price, 1991, as cited in Ayden, 2008). In addition to it, the research findings of Cheng (2005) described fear of negative feedback with high mean score 3.16 followed by communication apprehension 3.12 and test anxiety 3.05. In the similar vein, engineering students' somewhat higher levels of anxiety varied from the research results of Mari et al. (2012), who reported somewhat fair amount of foreign language anxiety of students in Pakistani context.

In this regard, Tanveer (2007) has reported differences in learning, learning problems and social status of the learners as one of the main anxiety provoking sources in his research. Similarly, Mak (2011) confirmed that students expressed fear of speaking when they were not prepared for the task. Speaking without preparation was the source which caused anxiety. In addition to it, more factors were identified as speech anxiety, fear of negative evaluation, feeling uncomfortable with natives, negative attitude towards English classroom and negative self-evaluation. (1) personal and interpersonal issues, (2) instructor and learner interactions, (3) classroom procedures, (4) language testing, (5) instructor beliefs about language learning, (6) learner beliefs about language learning (Young, 1991); age achievement, visit to foreign country, school experience, language course, perceived scholastic competence, and ideal self (Onwuegbuzie et al., 2000); speaking as the main source (Price, 1991); (1) communicative competence, (2) language anxiety, (3) risk taking, (4) learners' beliefs, (5) classroom environment, (6) group cohesiveness, (7) teacher support, (8) classroom organization (Wen \& Clement, 2003; Peng, 2007); the fear of failing class, fear of unfavourable impression on others, negative judgment by others, and fear of doing and saying wrong things (Shabani, 2012).

The present study supported and confirmed the findings of earlier explored factors in research on foreign language anxiety. Mostly common factors reported in research are; fear of evaluation, speaking in front of others, self-evaluation, making mistakes, oral presentations (Haiti, 2014). In this study, the results of anxiety-causing sources are consistent with Tallon's (2008) research which suggests learners' low self-esteem, competitiveness, self-perceived low levels of ability; and teacher's attitude and harsh manner of teaching. The current study also supports some highlighted sources such as teacher' behaviour, proficiency, lack of vocabulary, competiveness, and learner beliefs (Effiong, 2016). As discussed in the present study, there are many claimed sources of classroom anxiety, such as proficiency (Ewald, 2007; Liu \& Jackson, 2008; Toth, 2010); learner perceptions (Yan \& Horwitz, 2008); learner attitude to L2 (Mak, 2011); setting high standards (Kunt \& Tum, 2010); lack of knowledge of vocabulary and syntax (Koçak, 2010, as cited in Effiong, 2016); classroom procedures, teacher behaviour, and learner and instructor beliefs (Kim, 2009; 2010). In line with previous research, the current study has confirmed that English language learners' anxiety is caused by classroom sources including teachers as well as learners.

\section{Conclusion}

Foreign language anxiety research has provided a very meaningful insights of learners at the tertiary level. The qualitative and quantitative responses have generated a sound discussion on a very complex and multifaceted phenomenon of anxiety in research. This study was basically an attempt to investigate engineering student's anxiety-provoking sources in learning at Mehran university of Engineering and Technology, Pakistan. The complex issue of learning was searched in view of research objectives of this study. The quantitative part has provided test anxiety, communication apprehension and fear of negative evaluation as the basic sources of student's anxiety. Similarly, semi-structured interviews have provided a deep understanding of the sources which caused anxiety. It can be stated that few studies on anxiety factors have reported that it is mostly caused because of classroom factors. As this study has identified and replicated presentations, language instructor, comparison, self-negative evaluation, fear of making mistakes, individual language tasks and English linguistics difficulties 
as most frequently mentioned anxiety sources. Therefore, it is concluded in view of the results that this research has supported and confirmed previous explored factors of anxiety.

\section{Acknowledgment}

This research paper is the part of $\mathrm{PhD}$ thesis. It is published as the requirement for the PhD thesis, IELL, University of Sindh, Pakistan.

\section{References}

Aida, Y. (1994). Examination of Horowitz, Horowitz, and Cope's construct of foreign language anxiety: The case of students of Japanese. Modern Language Journal, 78(2), 155-168. https://doi.org/10.1111/j.1540-4781.1994.tb02026.x

Aydin, S. (2008). An investigation on language anxiety and fear of negative evaluation among Turkish EFL learners. Asian EFL Journal, 30(1), 421-444.

Bailey, P., Daley, C. E., \& Onwuegbuzie, A. J. (1999). Foreign language anxiety and learning style. Foreign Language Annals, 32(1), 63-76. https://doi.org/10.1111/j.1944-9720.1999.tb02376.x

Cheng, C. J (2005). The relationship to foreign language anxiety of oral performance achievement, teacher characteristics and in class activities. Master's dissertation, Ming Chuan University, China.

Chu, H. N. R. (2008). Shyness and EFL learning in Taiwan: A study of shy and non-shy college students' use of strategies, foreign language anxiety, motivation, and willingness to communicate. Available from ProQuest Dissertations and Theses database.

Effiong, O. (2016), Getting Them Speaking: Classroom Social Factors and Foreign Language Anxiety. TESOL Quarterly, 7, 132-161. http://doi.org/10.1002/tesj.194

Ewald, J. D. (2007). Foreign language learning anxiety in upper-level classes: involving students as researchers. Foreign Language Annals, 40(1), 122-142. https://doi.org/10.1111/j.1944-9720.2007.tb02857.x

Gkonou, C. (2011). Anxiety over EFL speaking and writing: A view from language classrooms. Studies in Second Language Learning and Teaching, 1(2), 267-281. https://doi.org/10.14746/ssllt.2011.1.2.6

Gopang, I. B., Ansari, S., Kulsoom, U., \& Laghari, A. (2017). An empirical investigation of foreign language anxiety in Pakistani University. International Journal of English Linguistics, 7(2), 21. https://doi.org/10.5539/ijel.v7n2p21

Gopang, I. B. (2016). Investigating foreign language learning anxiety among students majoring and non-majoring in English at public sector university, Pakistan. Unpublished Master Thesis, University of Sindh. Pakistan

Harati, R. D. (2014). Foreign Language Classroom Anxiety and Learners' Beliefs. The Iranian EFL Journal, 17(4), 98.

Hofer, B. K., \& Pintrich, P. R. (1997). The development of epistemological theories: beliefs about knowledge and knowing and their relation to Learning. Review of Educational Research, 67(1), 61-69. https://doi.org/10.3102/00346543067001088

Horwitz, E. K. (2016). Reflections on Horwitz (1986), "Preliminary Evidence for the Validity and Reliability of a Foreign Language Anxiety Scale". TESOL Quarterly, 50(4). https://doi.org/10.1002/tesq.295

Horwitz, E. K. (2010). Foreign and second language anxiety. Language Teaching, 43, 154-167. https://doi.org/10.1017/S026144480999036X

Horwitz, E. K., Horwitz, M. B., \& Cope, J. A. (1986). Foreign language classroom anxiety. Modern Language Journal, 70, 125-132. https://doi.org/10.1111/j.1540-4781.1986.tb05256.x

Hsieh, H.-F., \& Shannon, S. E. (2005). Three approaches to qualitative content analysis. Qualitative Health Research, 15(9), 1277-1288. https://doi.org/10.1177/1049732305276687

Kim, S.-Y. (2010). Is foreign language classroom anxiety context free or context dependent? Foreign Language Annals, 43(2), 187-189. https://doi.org/10.1111/j.1944-9720.2010.01073.x

Kim, S.-Y. (2009). Questioning the stability of foreign language anxiety and motivation across different classroom contexts. Foreign Language Annals, 42, 138-157. https://doi.org/10.1111/j.1944-9720.2009.01012.x 
Kunt, N., \& Tum, D. O. (2010). Non-native student teachers' feeling of foreign language anxiety. Procedia Social and Behavioral Sciences, 2, 4672-4676. http://doi.org/10.1016/j.sbspro.2010.03.748

Greene, J. C. (2007). Mixed methods in social inquiry. San Francisco: Jossey-Bass.

Creswell, J. W. (2003). Research design: Qualitative, quantitative, and mixed methods approaches. Thousand Oaks, CA: Sage.

Jones, J. F. (2004). A cultural context for language anxiety. EA Journal, 21(2), 30-39.

Liu, M., \& Jackson, J. (2008). An exploration of Chinese EFL learners' unwillingness to communicate and foreign language anxiety. The Modern Language Journal, 92(1), 71-86. https://doi.org/10.1111/j.1540-4781.2008.00687.x

MacIntyre, P. D., \& Gregersen, T. (2013). Emotions that facilitate language learning: The positive-broadening power of the imagination. Studies in Second Language learning \& Teaching, 2, 193-213. https://doi.org/10.14746/ssllt.2012.2.2.4

Mari, M. A., Umrani, T. H., \& Umrani, S. (2012). An investigation of Pakistani EFL learners' communication anxiety. ELF Annual Research Journal, 14, 31-43.

Merc, A. (2011). Sources of foreign language anxiety. A qualitative inquiry. Turkish Online Journal of Qualitative Inquiry, 2(4).

Peng, J. (2007). Willingness to communicate in an L2 and integrative motivation among college students in an intensive English language program in China. University of Sydney Papers in TESOL, 2(1), 33-59.

Price, M. L. (1991). The subjective experience of foreign language anxiety: Interviews with highly anxious students. In E. K. Horwitz \& D. J. Young (Eds.), Language anxiety: From theory and research to classroom implications (pp. 101-108). Upper Saddle River, NJ: Prentice Hall, Inc

Ohata, K. (2005). Potential sources of anxiety for Japanese learners of English: Preliminary case of interviews with five Japanese college students in the US. TESL-EJ, 9(3), 2-23.

Onwuegbuzie, A. J., Bailey, P., \& Daley, C. E. (2000). The validation of three scales measuring anxiety at different stages of the foreign language learning process: The input anxiety scale, the processing anxiety scale, and the output anxiety scale. Language Learning, 50(1), 87-117. https://doi.org/10.1111/0023-8333.00112

Onwuegbuzie, A. J., Bailey, P., \& Daley, C. E. (1999). Factors associated with foreign language anxiety. Applied Psycholinguistics, 20(2), 217-239. https://doi.org/10.1017/S0142716499002039

Oxford, R. (1999). Style wars as a source of anxiety in language classrooms. In D. J. Young (Ed.), Affect in foreign language and second language learning: A practical guide to creating a low-anxiety classroom atmosphere (pp. 216-237). Boston, MA: McGraw-Hill College.

Pappamihiel, N. E. (2002). English as a second language students and English language anxiety: Issues in the mainstream classroom. Research in the Teaching of English, 327-355.

Schreier, M. (2012). Qualitative content analysis in practice. Los Angeles: Sage

Shabani, M. B. (2012). Levels and sources of language anxiety and fear of negative evaluation among Iranian EFL learners. Theory and Practice in Language Studies, 2(11), 2378-2383. https://doi.org/10.4304/tpls.2.11.2378-2383

Shao, K., Yu, W., \& Ji, Z. (2013). An exploration of Chinese EFL students' emotional intelligence and foreign language anxiety. Modern Language Journal, 97, 917-929.

Tallon, M. (2008). A culture of caring: Reducing anxiety and increasing engagement in first year foreign language courses. Collaborating for Student Success: Building Engagement in Learning, University of the Incarnate Word, San Antonio, TX.

Tanveer, M. (2007). Investigation of the factors that cause language anxiety for ESL/EFL learners in learning speaking skills and the influence it casts on communication in the target language. Master's thesis, Faculty of education, University of Glasgow.

Toth, Z. (2010). Foreign language anxiety and the advanced language learner: A study of Hungarian students of English as a foreign language. Newcastle upon Tyne: Cambridge Scholars. 
Waseem, F., \& Jibeen, T. (2013). Anxiety amongst learners of English as a second language. An examination of motivational patterns in the Pakistani context. International Journal of Humanities and Social Sciences, 3, 116.

Wei, J. (2014). A study via interviews of the Chinese Bouyei college learners' EFL classroom anxiety arousals. Journal of Language Teaching and Research, 5(2), 419-428. https://doi.org/10.4304/j1tr.5.2.419-428

Yan, J. X., \& Horwitz, E. K. (2008). Learners' perceptions of how anxiety interacts with personal and instructional factors to influence their achievement in English: A qualitative analysis of EFL learners in China. Language learning, 58(1), 151-183. https://doi.org/10.1111/j.1467-9922.2007.00437.x

Zhao, A. (2009). Foreign language reading anxiety: Investigating English-speaking university students learning Chinese as a foreign language in the United States (Doctoral dissertation). Retrieved from ProQuest Dissertations and Theses database (UMI No. 3374058).

\section{Copyrights}

Copyright for this article is retained by the author, with first publication rights granted to the journal.

This is an open-access article distributed under the terms and conditions of the Creative Commons Attribution license (http://creativecommons.org/licenses/by/4.0/). 